DOI 10.31392/NPU-nc.series15.2021.11(143).03

\author{
Sobolenko A., \\ senior lecturer at the Department of Health Technology and SportsNational Technical University of Ukraine \\ "Kyiv Polytechnic Institute named after Igor Sikorsky" \\ Koryukaev $M$. \\ senior lecturer at the Department of Health Technology and Sports \\ National Technical University of Ukraine "Igor Sikorsky Kyiv Polytechnic Institute" \\ Martinov Yu. \\ senior lecturer at the Department of Health Technology and Sports \\ National Technical University of Ukraine "Igor Sikorsky Kyiv Polytechnic Institute"
}

\title{
PECULIARITIES OF FORMATION OF MOTIVATION OF STUDENT YOUTH TO EXERCISES
}

The article reveals the peculiarities of forming students' motivation to exercise. It is established that the formation of motivation for exercise is a complex systemic process that includes many components.

One of the indicators of students' health is their motivation to exercise. Exercise is an element that closely connects all aspects of personality in the process of development and formation. The main task of physical education in the educational process is to preserve the health of students, the development of skills necessary for the formation of a competitive specialist. The article focuses on the motivation to exercise not only during the educational process, but also in everyday life, and also substantiates the importance of physical activity for the normal functioning of the human body.

Theoretical knowledge and practical experience gained during physical culture and sports practice form a personality's outlook in the field of physical culture and the need for it. The spectrum of these needs is quite wide: this is the need for movement and physical activity, for communication, contacts and spending free time with friends; in games, emotional relaxation, self-affirmation, strengthening the position of one's "I", in cognition and in physical improvement. Mastering the knowledge system helps to form the need for physical exercises. It also allows students to independently use the means of physical culture, providing adequate self-esteem and self-control.

The search for methods of increasing motivation for physical education, it is motivation that is an integral component of successful physical culture and sports activity. Preserving and strengthening the health of the student body will prepare competent specialists who are ready for productive and long-term professional activity.

Key words: motivation, physical exercises, healthy lifestyle, students.

Соболенко А. І., Корюкаєв М. М., Мартинов Ю. О. Особливості формування мотивації студентської молоді до занять фізичними вправами. В статті розкрито особливості формування мотивації студентів до занять фізичними вправами. Встановлено, що формування мотивації до занять фрізичними вправами складний системний процес, який охоплює безліч компонентів.

Одним із показників здоров'я студентів $є$ їхня мотиваиія до занять фрізичними вправами. Фізичні вправи слугують тим елементом, що тісно пов'язує між собою в процесі розвитку і становлення всі сторони особистості. Головним завданням фізичного виховання в освітньому процесі $\varepsilon$ збереження здоров'я студентів, розвиток здібностей необхідних для фрормування конкурентноспроможного фрахівця. У статті акцентується увага на мотивації до занять фізичними вправами не тільки під час освітнього процесу, а й у повсякденному житті, а також обгрунтовується значення рухової активності для нормальної життєдіяльності організму людини.

Ключові слова: мотивація, фізичні вправи, здоровий спосіб життя, студенти.

Formulation of the problem. In modern society, the requirements for the physical fitness of young people, which are necessary for work, are increasing. Society needs a "workforce" with a high level of physical and mental performance. Student youth are the main labor force of the country, and their health and well-being determines the health and well-being of the nation. However, practice shows that the state of health of students does not correspond to the demands of today. One of the main reasons affecting the health of young people is the level of physical activity.

Because physical activity is a direct indicator of health quality, therefore it is for the development of new programs in physical education, for search ways to improve financially - technical base and development of motivation in students should be given the most attention. IN in a pandemic that has swept the world, the problem of low, even the critical level of health of the population. Given the decline in living standards, which is caused socially - economic cataclysms in society, deteriorating eco logical situation, emotionally - stress loads that have a negative impact on social, spiritually - moral, psychological and physical sphere of man, the primary It is important to solve the problems of physical health of modern youth. Regarding the indicators in the state, the situation has long wanted to be better. Unfortunately, Ukraine occupies one of the last places among the developed countries of the world, according to quality of human health: by the number of diseases, by duration treatment, etc. Accordingly, the deficit of physical activity especially negative affects the health of different populations. Healthy Lifestyle modern man, based on the principles of rational organization, active activity and creative development, inextricably linked with the physical education.

Analysis of literature sources. Cheshihina V.V., Kulakov V.I., Filimonov S.N. in their works they note that the majority of 
students have a positive-passive attitude towards physical culture, and about $20 \%$ have a negative attitude towards physical exercises. This may indicate an unformed need for physical exercise. Which, in turn, indicates a low level of motivation for physical education. Currently, one of the urgent problems is the effective organization of physical education classes for young people in universities. The main component for the successful implementation of any activity, including physical culture and sports, is motivation.

A low level of motivation for physical education, respectively, reduces physical activity, which also leads to a decrease in the level of physical and mental performance, physical fitness and physical development of students. In this regard, it is important to study the structure of the motivational complex for physical education. Search for new means and methods that encourage physical education. The search for methods of increasing motivation for physical education, it is motivation that is an integral component of successful physical culture and sports activity. Preserving and strengthening the health of the student body will prepare competent specialists who are ready for productive and long-term professional activity.

Presentation of the main research material. Determination of motivational priorities and interests of students in physical education and sports will make it possible to form needs for systematic physical exercises, to determine the effectiveness of building the process of physical training of students of higher educational institutions. The purpose of our research was to study the interests and needs of students in the field of physical culture. Object of research: the process of physical education of TSU students, the direction of training, which is not related to physical culture. Subject of research: preferences in the field of physical culture of students studying in various areas of training at TSU.

To achieve the goal, the following tasks were set:

1. To study the methodological literature on this topic and develop a questionnaire to determine the preferences of TSU students.

2. Based on the results of the questionnaire, determine the priority areas in the field of physical culture for TSU students studying in areas of training not related to physical culture. As already mentioned, the main component for the successful implementation of any activity, including physical culture and sports, is motivation. In modern science, there are various approaches to the problem of motivation.

P.A. Rudik and the authors consider the motive as a conscious need, A.I. Leont'ev and other authors understand a motive as a concrete or abstract object that satisfies a need. It is advisable to combine the two points of view: without need, an object that satisfies the need-goal is not needed, but even without a goal, need will not lead to conscious and directed activity. Thus, the motive is the inner state of the personality, which determines and directs its actions at every moment of time, the formed justification of its action. The core of any activity is the need-motivational component.

Motivation is the main component of successful performance. At the heart of any business is a need. The need for movement, the need for physical improvement, the need for maintaining and strengthening health - these are the psychological foundations of physical culture and sports. Thus, for the formation of motivation for physical education, it is necessary to create interest in classes, to form the need for physical self-improvement and the need for regular exercises, in order to improve the level of health, increase mental and physical performance. The basis for the formation of a need is knowledge. Knowledge influences motives and interests in a formative way.

Knowledge about the significance of a particular type of activity for an individual forms the need for motor activity. It is necessary to inform students about the effect of physical exercise on the body, health and performance. Research conducted by L.I. Bozhovich, O.V. Dashkevich, V.I. Kovalev, A.M. Matyushkin, identified the important role of cognitive motives for solving fundamental problems of the development and activity of the individual, the effectiveness of training, the formation of inclinations and abilities. The basis of motivation is cognitive activity.

Theoretical knowledge and practical experience gained during physical culture and sports practice form a personality's outlook in the field of physical culture and the need for it. The spectrum of these needs is quite wide: this is the need for movement and physical activity, for communication, contacts and spending free time with friends; in games, emotional relaxation, self-affirmation, strengthening the position of one's "I", in cognition and in physical improvement. Mastering the knowledge system helps to form the need for physical exercises. It also allows students to independently use the means of physical culture, providing adequate self-esteem and self-control.

Mastering the knowledge system helps to form the need for physical exercises. It also allows students to independently use the means of physical culture, providing adequate self-esteem and self-control. A number of studies show that physical activity becomes significant if it is associated with opportunities for self-realization in future professional and family life. Awareness of the influence of physical exercises on the body in terms of physiology, opportunities for technical growth, allows you to form conscious goals.

Thus, theoretical training contributes to the formation of a conscious need for physical education. The principle of consciousness during the period of active development of intelligence acquires fundamental importance in the formation of motivation. Thus, the basis of the entire motivational - forming process is based on the principle of consciousness and activity, nothing can be introduced into the consciousness of a person with his passive or negative attitude. O.D. Dubogay, I. V. Efimova, K. P. Kozlova, T.Yu. Krucevich "Conscious attitude to physical exercise and the effect is observed where students clearly know for what purpose they need to practice, what level to achieve and what it can be useful in the future." The activity of an action or activity depends on the internal position of the individual and emotional experiences.

As a result of a survey and questioning of students, whose education is not related to physical culture, the main groups of motives were identified: - Wellness - health promotion and disease prevention; · Motor - activity - the development of organs and systems of the body; - Competitive - competitive - the desire to improve sports achievements, the desire to win; · Aesthetic improving the appearance, improving the physique; · Emotional - getting pleasure, good mood; · Administrative - receiving credit; 
- Communicative - communication. So, as a result of processing the test results, the students give preference to the types of physical culture activity: $50 \%$ - aimed at the formation of an aesthetically beautiful physique, $30 \%$ - health promotion, $20 \%$ emotional satisfaction. Thus, the majority of female students choose fitness classes (aerobics, shaping, step aerobics, stretching, etc.). The motivation of boys is somewhat different from the motivation of girls. $10 \%$ - students are motivated for physique aesthetics, $10 \%$ are motivated to enjoy the lessons, $20 \%$ are motivated to improve health and improve performance, $60 \%$ of respondents are focused on self-improvement (achievement of high sports results, development of physical qualities, improvement of motor skills and abilities). Young men prefer athletic gymnastics, martial arts, sports games.

An active interest in physical culture and sports is formed when external motives and goals correspond to the capabilities of those involved, that is, they are optimal for him. Excessively difficult or excessively light modes of external motivation give a negative result, internal motivation and interest are not formed, emotions of anxiety and self-doubt arise in the first case, and in the second, emotions of boredom and indifference.

The successful implementation of motives and goals causes satisfaction with the result, inspiration with success and a desire to continue classes on their own initiative, thus, an interest in classes is formed, and, consequently, internal motivation. Intrinsic motivation also arises when the trainees experience satisfaction from the process itself, the conditions of the classes, the nature of the relationship with the teacher, classmates during these classes.

A number of authors believe that great damage to physical education is caused by the priority of the normative approach, when the focus is not on the interests of students, but on its external indicators, characterized by the control standards of the curriculum. And as a result, interest in the very discipline "Physical education" is lost, attendance and effectiveness of classes decreases. Physical education programs involve the use of external motives. As a result of the analysis of scientific and methodological literature and conversations with university teachers, it was revealed that physical culture programs of universities are drawn up without taking into account the interests of students.

Consequently, it is necessary to form a process, as a result of which physical culture lessons acquire a personal meaning, create the stability of interest, turning the external given motives of activity into the internal needs of the individual. Thus, we come to the conclusion that for the formation of motivation it is necessary to identify the needs and motives of the students themselves for physical education. As a result of the conducted questionnaire and survey, we received that the physical culture and sports activity of students arises from different needs, they can be divided into three groups: The need for movement, The need for sports activities.

The very concept of "sport" is viewed differently by boys and girls. For most girls, going in for sports is one of the means aimed at having a beautiful figure, correct posture. It is more typical for young men to strive to improve as much as possible in their chosen sport in order to achieve the best sports result. According to the research results, the motivation of young men is aimed at the development of physical qualities: strength, dexterity, endurance, speed, and the studies of a number of authors indicate that the dominant motives of students and female students to physical culture are the desire for body beauty, the development of strength

Conclusions. The research made it possible to reveal the motivation of students and female students to physical education, depending on the desire to look good, strengthen and maintain health, develop and improve motor skills and abilities, and get positive emotions. The research has shown that students 'and female students' motivation for physical education is different. When forming a physical education program, it is necessary to take into account the identified motives and individual preferences, as well as use a variety of physical education classes, increasing the number of sports and health-improving physical culture, which could arouse and maintain the interest of any contingent of students. These studies should be taken into account when developing a physical education program, as this will help to effectively implement the process of physical education at a university and form students' conscious motivation for physical education.

\section{References}

1. Kanishevs'kyy S. M. Umovy, stan i perspektyvy rozvytku fizychnoho vykhovannya u vuzakh Ukrayiny / S. Kanishevs'kyy, R. Rayevs'kyy, V. Krasnov, A. Rybkovs'kyy, S. Prysyazhnyuk, N. Tret'yakov // Teoriya i praktyka fizychnoho vykhovannya. - 2008. - № 1. - S. 139-145.

2. Krutsevych T. Yu. Spryamovanist' tsinnostey indyvidual'noyi fizychnoyi kul'tury studentiv riznykh viddilen' vuzu / T. Krutsevych, O. Marchenko // Sportyvnyy visnyk Prydniprov"ya. - 2008. - № 3-4. - S. 103-107.

3. Lynets' M. Osnovy metodyky rozvytku rukhovykh yakostey : navch. posib. dlya fizkul'turnykh vuziv / M. Lynets'. L'viv : Shtabor, 1997. - $204 \mathrm{~s}$.

4. Lavrenyuk V. S. Udoskonalen-nya power health of students in the initial process of physical education / Lavrenyuk V. S. // Pedagogy, psycho-logic and medical-biological problems of physical education and sports: zb. sciences. pr. Kharkiv: HDADM, 2011. - No6. - P.74-76.

5. Matveev L. P. Teoryya y metodyka fyzycheskoy kul'turb / L. Matveev. - M. : Fyzkul'tura y sport, 2008. $-544 \mathrm{~s}$.

6. Prykhod'ko V. V. Reformuvannya vyshchykh navchal'nykh zakladiv fizychnoyi kul'tury i sportu v Ukrayini / V. Prykhod'ko // Teoriya i praktyka fizychnoho vykhovannya. - 2008. - №1. - S. 74-85.

7. Ogar G. O. Injection of the program of strength training with the added value of the growth of directness to the physical development and preparation of the children of 15-17 years / G. O. Ogar, V. A. San-zharov, V. I. Lasitsya, Є. G. Ogar /I Theory and technique of physical education. - 2011 .-- No.10. - P.37-42.

8. Shyyan B. Teoriya i metodyka fizychnoho vykhovannya shkolyariv / B. Shyyan. - Ch. 1. - Ternopil' : Navch. kn.Bohdan, 2003. $-272 \mathrm{~s}$. 